\title{
The Impacts of Hyperlinks and Writer Information on the Credibility of Stories on a Participatory Journalism Web Site
}

\author{
Kirsten A. Johnson \\ Drexel University, 3141 Chestnut St., Philadelphia, Pa., 19104 \\ kaj27@drexel.edu
}

\begin{abstract}
Credibility in mainstream media continues to wane, giving rise to new forms of journalism supported by the Internet. One of these new forms of journalism is participatory journalism. This is a form of journalism in which content is produced by ordinary citizens, usually on web sites. One of the most popular participatory journalism web sites at this time is ohmynews.com. Like mainstream media, this site, as well as ones like it, have credibility obstacles to overcome. This paper outlines a proposed study in which the researcher will test whether or not the presence of information about a writer and sources used to write a story on a participatory journalism web site affects the perceived credibility of the story.
\end{abstract}

Keywords: Participatory journalism, Citizen journalism, weblogs, blogs, computer mediated communication, CMC, credibility

Research Area: Participatory journalism, blogging, user created content, computer mediated communication.

Brief Description of Research Topic: Participatory journalism and markers of credibility. Does providing information about the writer of a story and sources used to write the story affect its credibility?

\section{Introduction}

This proposed study seeks to understand the relationship between information and credibility. Credibility is one of the key components upon which journalism is built. Once credibility is compromised it can be detrimental to a news organization. One of the ways traditional media try to lend a measure of credibility to their information is by adhering to a filter-then-publish model. This means that the information that comes into a newsroom is edited prior to being released to a mass audience. Conversely, participatory journalism web sites tend to operate under a publish-thenfilter model, where information is released to the mass audience and then it is edited. In some cases people with journalism experience are employed as editors, whereas in other cases, visitors to the site can act as editors. The missing layer of editorial oversight may cause credibility problems for these sites [1].

A study [2] on which elements help and hurt the perceived credibility of web sites shows that including markers of expertise can help boost the perceived credibility of 
the site. The authors of the study suggest web sites can convey expertise through listing information about the author, as well as citations of, and references to, the author's work. The authors of the study also point out that they believe many sites miss the chance to convey this expertise to those who visit their sites.

Building upon this study, perhaps participatory journalism sites can improve perceived credibility by providing information about those who write on the sites, as well as allowing visitors to their sites to verify information easily through the use of hyperlinks embedded in the story.

While there have been many studies done on traditional media and credibility perceptions, there haven't yet been any credibility studies done that pertain exclusively to participatory journalism. In fact, scholarly literature on participatory journalism is scant, so this study seeks to add to this body of literature, as well as build on previous studies in the areas of web credibility and trust.

\subsection{Antecedents to Participatory Journalism}

The idea of allowing ordinary citizens to have a voice in news coverage is not a new one. The civic, or public journalism movement, allows the concerns of citizens to help shape the news agenda [3, 4, 5]. The presidential election in 1988 is often cited as the time civic journalism emerged. During this time journalists raised concerns that the election news being covered wasn't news that was of interest to citizens, and that journalists hadn't remembered the public in their coverage [5]. The rise of civic journalism was spurred by declining newspaper readership and increased competition in the delivery of news, particularly 24 hour news stations like CNN [3].

Tom Curley, President and CEO of the Associated Press [6], notes that the Internet has played a large role in altering the news landscape and giving a boost to the civic journalism movement.

Consumers will want to use the two-way nature of the Internet to become active participants themselves in the exchange of news and ideas. The news, as 'lecture,' is giving way to the news as a "conversation." (para. 40)

Gill [7] argues that this idea of news as "conversation" has helped give rise to participatory journalism web sites, because participatory journalism expands two-way communication between readers and media. Interaction often is encouraged between journalists and readers. Blogging is another way to encourage interaction between writers and readers because it provides different viewpoints on shared experiences [7]. It can also be used as a tool for journalists to help "serve as a collective databank used to jog the faulty memories of those who write or report for major media" [7], p. 2.

Weblogs, also known as blogs, pre-date the creation of participatory journalism sites. Some argue that blogs can be considered a form of participatory journalism if they include journalistic news content $[7,8]$.

\subsection{Participatory Journalism}

Participatory journalism, also referred to as "grassroots journalism" and "citizen journalism," is the idea that news content is produced by ordinary citizens with no formal journalism training [9]. In their paper titled We Media: How Audiences are 
Shaping the Future of News and Information, Shayne Bowman and Chris Willis [9] use the following working definition of participatory journalism:

The act of a citizen, or group of citizens, playing an active role in the process of collecting, reporting, analyzing and disseminating news and information. The intent of this participation is to provide independent, reliable, accurate, wide-ranging and relevant information that a democracy requires. (p. 9)

Media futurists predict that by the year 2021 citizens will produce $50 \%$ of the news peer to peer [9]. Despite worries about citizen journalism weakening traditional journalism, some traditional media outlets have embraced reports by citizen journalists. Coverage of large-scale disasters by citizens, beginning in 2004, when a tsunami hit South Asia, helped fuel the participatory journalism movement. Shortly after the event, tourists took more than 20,000 tsunami pictures and posted them to Flickr.com. The London bombings on July 7, 2005 allowed citizens to become involved in media coverage. Video shot from citizens' camera phones was used in the BBC's coverage of the bombings that evening. The BBC reports citizens sent more than 20,000 e-mails, 1,000 pictures, and 20 videos within the first 24 hours following the bombing [10].

Hurricane Katrina in 2005 spurred major traditional media sources to solicit pictures, stories, and video from their audience. Although major news organizations like CNN, MSNBC, and The New York Times received a lot of material from citizens, little of it was used [11].

Arguably the most well-known and popular participatory journalism web site in the world is ohmynews.com, founded by Oh Yeon Ho of South Korea in February 2000. Ohmynews.com has more than 42,000 registered citizen journalists and 95 full-time staff [12]. Editors review and post hundreds of articles a day written by the citizen journalists. The most carefully edited articles are located prominently on the page. The articles that have not been edited yet are featured less prominently on the page [13]. From February 2005 through July 2005 ohmynews.com had anywhere from about 3 million to about 18 million page views per day [14].

As trust in traditional media continues to wane, more people are going online to get their news. About 50 million Americans get their news from the Internet in a typical day [15].

\section{Research Questions}

The lack of research on markers that lead to higher levels of perceived credibility of participatory journalism web sites has led to this study's three main research questions.

RQ 1: To what extent does providing information about a writer's background and providing a picture of the writer on a participatory journalism site affect the perceived credibility of the story?

Previous studies $[2,16,17]$ show that providing information about the author of online information as well as a picture may enhance the credibility of the site. The researcher believes that this finding can be extended to individual stories on a 
participatory journalism web site. The researcher hypothesizes that providing both information about the writer's background and providing a picture of the writer will enhance the credibility of stories found on the participatory journalism site ohmynews.com. In this study, "information about a writer's background" is defined as information about the life and previous activities of the author of a news article on the ohmynews.com web site. "Perceived credibility" in this study will be assessed as it has been in a number of previous studies, by measuring the following: believability, accuracy, trustworthiness, bias, and completeness [18, 19, 20, 21, 22].

RQ 2: To what extent do hyperlinks that allow users to verify information contained in a story on a participatory journalism site affect the perceived credibility of the story?

Hyperlinks can be important in helping users form judgments about online credibility [16, 23]. The researcher hypothesizes that stories on the participatory journalism web site ohmynews.com that contain hyperlinks will be rated by participants as more credible than stories that do not contain hyperlinks.

RQ3: To what extent does providing information about a writer's background, a picture of the writer, and hyperlinks that allow users to verify information contained in a story on a participatory journalism site affect the perceived credibility of the story?

Research Question 3 seeks to examine the interaction of all the factors. The researcher hypothesizes that the stories on the participatory journalism site ohmynews.com that contain all of these pieces of information (writer information, a picture, and hyperlinks) will be rated by participants as more credible than stories that don't contain all of the above information.

\subsection{Procedures}

The study will include 120 participants. These participants will be undergraduate students at Elizabethtown College, who are at least 18 years of age. The entire study will be done online. The participants will be divided into four groups. One group will see only the stories, one group will see the stories and the writer information, one group will see the stories and the hyperlinks, and one group will see the story, the writer information and the hyperlinks. Each group will read the same three stories (one hard news story, one feature story, and one sports story). After reading each story they will fill out a questionnaire, about the credibility of the story they just read.

In addition to collecting information from participants using questionnaires, information will also be collected using a commercially available tracking software program. This will allow the researcher to collect information concerning how long participants took to read each story, and which hyperlinks participants clicked on, if any, in each story.

\subsection{Analysis}

The results from the questionnaires filled out by all of the groups will be analyzed to determine whether or not the perceived credibility of the story changed when the following variables: the presence of information about the writer, hyperlinks, and both 
the information about the writer and the hyperlinks were introduced. The independent variables in the study are the information about the writer and the hyperlinks, and conversely the absence of that information. The dependent variable will be the change in perceived credibility between the 4 groups. The change in credibility will be calculated using a one-way ANOVA at the .05 significance level.

\section{Expected Contributions}

This study will add to the small, but growing body of literature on participatory journalism. To date, there have not been any studies that have examined markers of credibility on participatory journalism sites, so this would be the first. This study will also help those creating participatory journalism sites understand how to make their sites more credible to users. User created content is becoming more prevalent on the web, and studies aimed at examining this phenomenon will be needed to understand this new generation of content creators. This study is just the first, of many possible studies, that will look at this growing trend of online content creation.

\section{References}

1. Gilster, P.: Digital Literacy. John Wiley \& Sons, New York (1997)

2. Fogg, B.J., Marshall, J., Laraki, O., Varma, C., Fang, N., Paul, J., et al.: What Makes Websites Credible? A Report on a Large Quantitative Study. In: Proceedings of the Conference on Human Factors in Computing Systems CHI 2001 (March 31-April 5, 2001)

3. Eksterowicz, A.J., Roberts, R., Clark, A.: Public Journalism and Public Knowledge. Press/Politics 3(2), 74-95 (1998)

4. Grimes, C.: Whither the Civic Journalism Bandwagon? Press/Politics 2(3), 125-130 (1997)

5. Rosen, J.: What Are Journalists For? Yale University Press, New Haven (1999)

6. Curley, T.: Text of Opening Keynote by Tom Curley, http://journalist.org/2004conference/ archives/000079.php

7. Gill, K.E.: How Can We Measure the Influence of the Blogosphere? In: Paper presented at WWW2004, New York (May 17-24, 2004)

8. Blood, R.: Weblogs and Journalism: Do They Connect? Nieman Reports 57(3), 61-63 (2003)

9. Bowman, S., Willis, C.: We Media: How Audiences are Shaping the Future of News and Information (2003), http://www.hypergene.net/wemedia/weblog.php

10. Sambrook, R.: Citizen Journalism and the BBC. Nieman Reports 59(4), 13-16 (2005)

11. Bowman, S., Willis, C.: The Future Is Here, But Do News Media Companies See It? Nieman Reports 59(4), 6-10 (2005)

12. Ihlwan, M., Hall, K.: OhmyNews: Voices from the Street. Business Week Online, http://www.businessweek.com/magazine/content/06_20/b3984072.htm?campaig_id=search

13. Schroeder, C.M.: Is This the Future of Journalism? (2004), http://www.msnbc.msn.com/id/ 5240584/site/newsweek/

14. Alexa Internet, Inc., (2006), http://www.alexa.com/data/details/related_links?q=\&url=english.ohmynews.com

15. Horrigan, J.B.: Online News (2006),

http://www.pewinternet.org/ppf/r/178/report_display.asp 
16. Fogg, B.J.: Stanford Guidelines for Web Credibility (2002), http://www.webcredibility. org/guidelines

17. Fogg, B.J., Marshall, J.: Web Credibility Research: A Method for Online Experiments and Early Study Results. In: Paper presented at the Conference on Human Factors in Computing Systems CHI 2001, Seattle, WA (March 31-April 5, 2001)

18. Flanagin, A.J., Metzger, M.J.: The Perceived Credibility of Personal Web Page Information As Influenced by the Sex of the Source. Computers in Human Behavior 19, 683-701 (2003)

19. Gaziano, C., McGrath, K.: Measuring the Concept of Credibility. Journalism Quarterly 63, 451-462 (1986)

20. Johnson, T.J., Kaye, B.K.: Wag the Blog: How Reliance on Traditional Media and the Internet Influence Credibility Perceptions of Weblogs Among Blog Users. Journalism and Mass Communication Quarterly 81(3), 622-642 (2004)

21. Meyer, P.: Defining and Measuring Credibility of Newspapers: Developing an Index. Journalism Quarterly 65, 567-574 (1988)

22. Newhagen, J., Nass, C.: Differential Criteria for Evaluating Credibility of Newspapers and TV News. Journalism Quarterly 66, 277-284 (1989)

23. Stewart, K.J., Zhang, Y.: Effects of Hypertext Links on Trust Transfer. In: Paper presented at the ICEC 2003, Pittsburgh, PA (2003) 